\title{
Discussion on planning ideas of steel lo- gistics park in the low carbon perspective
}

\author{
WENG Xin-gang,WANG Xiao-kun \\ Beijing Wuzi University, Beijing, China \\ wengxingang@263.net, lavender48@126.com
}

\begin{abstract}
Under the background of fact that the low-carbon revolution of the whole world rises, this text carries on research to intension and characteristic of the low carbon type steel logistics park, analyze the current situation of the development of the low carbon logistics. Construct the planning framework of the low carbon type steel logistics park of our country through the MSFLB logistics park planning methodology, and specifically explained development planning and management mode of steel logistics park in the low carbon perspective, have implemented low-carbon idea in the application of steel logistics park planning, in the hope of offering the planning ideas of the low carbon type steel logistics park of our country.
\end{abstract}

Keywords: low carbon logistics; steel logistics park; park planning; business strategy

\section{Introduction}

In recent years, more than 100 large and medium steel logistics parks are completed or under construction. The logistics scale of steel in our country will increase at about $10 \%$ per year growth rate in the following five years. It certainly will aggravate the pressure at the surrounding environment. The steel logistics industry must pay attention to the energyconserving emission reduction of steel and iron industry to realize sustainable development, develop low-carbon logistics. Therefore, this paper canvasses the planning and construction ideas of the low carbon type steel logistics park emphatically, and set up planning framework, and make relevant management tactics of steel logistics park.

\section{Theoretical analysis of developing the low carbon steel logistics park}

\subsection{Intension of Low-carbon Logistics}

About the discussion of the low-carbon logistics, domestic academia has not formed overall and systematic definition yet, and foreign scholars tend to discuss how low carbon economy impact on modern logistics service. In this paper, low-carbon logistics is defined as: Proceed from the perspective of low carbonization logistics system operations, to adopt scientific and practical logistics technology, energy-saving technologies and planning methods, and organize to build low carbonization logistics system, aiming at reducing greenhouse gas emissions emerging in the procedure of logistics activities, and raising the energy utilization to reach achieve maximum efficiency of logistics systems.

\subsection{Low-carbon Logistics and Green Logistics}

In view of concept, green logistics and low-carbon logistics targets, technical methods and service objects are basically the same, low-carbon logistics is the im- 
portant constituent element of green logistics, and the category of the green logistics is more extensive. Low-carbon logistics should take on a higher level of green logistics concepts with environment growing and resources saving, not only pay close attention to the process of logistics activities impacting on environment, but also emphasize the economical use of energy, therefore bring the green efficient economic benefits.

\section{Analysis on planning and construc- tion of steel logistics park in the low carbon perspective}

\subsection{Intension of low-carbon Steel Lo- gistics Park}

Low-carbon type steel logistics park is based on energy-conserving technical application of low carbon, seeking low energy consumption, less-polluting and high benefit in steel logistics park. Planning and designing a new kind of steel logistics park which follow green environment protective idea and recycle economy development mode of steel industry, its key idea is energy-efficient systematic framework and low-carbon logistics activities.

\subsection{Planning Framework of low- carbon Type Steel Logistics Park}

1) Introduction of MSFLB Logistics Park Planning Methodology: in numerous practices of international logistics park planning project summed up "MSFLB" logistics park planning methodology based on three-driven that demanddriven, competition-driven, best practice-driven. MSFLB " five steps " , It is actually the abbreviation of the English first letter of these five steps to plan methodology, namely Market Analysis, Strategic Positioning, Function Design, Layout Design And Business Plan.

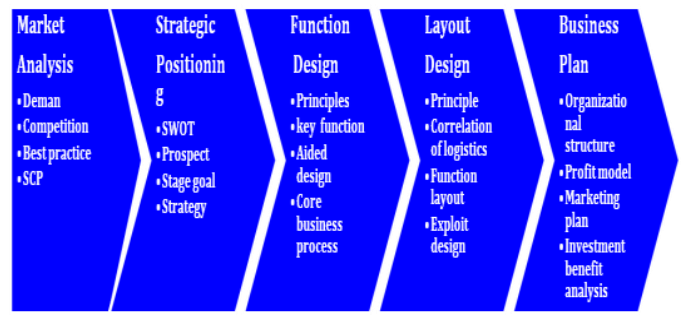

Figure1 The procedure of MSFLB logistics park planning methodology

2)Constructing the Suitable Planning Framework of Low-carbon Type Steel Logistics Park in Our Country: Reference MSFLB logistics park planning methodology to formulate a planning process, combined with specific characteristics of low-carbon steel logistics park, this paper argues, a low-carbon steel logistics park planning and construction of the basic framework and the core content, including the external market environment analysis, function positioning, function design, layout design, business model and strategies.

\section{Empirical analysis of low-carbon steel logistics park planning and con- struction}

In this paper, a large iron and steel manufacturing enterprises plans to build $\mathrm{H}$ low-carbon type steel logistics park in North China as the example, to discuss how to plan the function demand, function design and layout design of lowcarbon type steel logistics park.

\subsection{Analysis of the External Market Environment}

From the viewpoint of regional economy, the steel logistics and trade in North China is still relatively dispersed, the market needs further integration, to form the relatively concentrating modern steel trading centers, to promote the modernization of steel circulation. From the viewpoint of 
customer's demand, the market demands for modern steel logistics service and transaction mode grow with each passing day, urgently need a new logistics trade center to satisfy. Analyzing on industry competitors, it increase that cases of steel logistics park developed and constructed with the leading steel manufacturing enterprise, large-scale steel trade enterprises run by local people begin to march into the steel logistics park industry, too.

\subsection{Function Positioning}

$\mathrm{H}$ steel logistics park as the key project of logistics development planning of the large-scale steel producing enterprise, on the one hand, should form one's own logistics brand and service system progressively, to make it become the important carrier that extends the industry chain and expands logistics services. On the other hand, $\mathrm{H}$ steel logistics park should construct low-carbon business management mode, and establish low-carbon park image. Low-carbon corporate culture, lowcarbon service system, and low-carbon marketing form the main content of $\mathrm{H}$ steel logistics park inside low-carbon business management mode together.

\subsection{Function Design}

According to the on-the-spot investigation on service functions of steel logistics park and steel products trading market, as well as the proposed $\mathrm{H}$ steel logistics park of regional economic development level, industrial structure and characteristics, to confirm its logistics services object mainly for steel products trade dealers, end users of steel, some steel factories.

Table1. Function Design of Low-carbon Steel Logistics Park

\begin{tabular}{ll}
\hline \hline Function design & Features \\
\hline Trading of steel & $\begin{array}{l}\text { Introduce the iron and steel } \\
\text { trade circulating enterprises } \\
\text { products }\end{array}$ \\
\hline $\begin{array}{l}\text { Large-scale } \\
\text { storage }\end{array}$ & $\begin{array}{l}\text { Storage area set up,providing } \\
\text { diversified services. }\end{array}$ \\
\hline \hline
\end{tabular}

\begin{tabular}{ll}
\hline \hline $\begin{array}{l}\text { Transport and } \\
\text { distribution }\end{array}$ & $\begin{array}{l}\text { Set up logistics and transport } \\
\text { company, through its own } \\
\text { vehicles and the integration of } \\
\text { social resources. }\end{array}$ \\
\hline Steel Processing & $\begin{array}{l}\text { Providing steel products deep } \\
\text { processing service. }\end{array}$ \\
\hline $\begin{array}{l}\text { Electronic trading } \\
\text { platform }\end{array}$ & $\begin{array}{l}\text { Utilize third-party electronic } \\
\text { trading platform, launch } \\
\text { various forms of stock trading }\end{array}$ \\
\hline Financial support & $\begin{array}{l}\text { Launch logistics financial } \\
\text { services by cooperating with } \\
\text { bank }\end{array}$ \\
\hline Business Meeting & $\begin{array}{l}\text { Undertake the main assortment } \\
\text { steel international exhibitions, } \\
\text { trade fairs . }\end{array}$ \\
\hline Auxiliary services & $\begin{array}{l}\text { Provide complete support } \\
\text { services. }\end{array}$ \\
\hline \hline
\end{tabular}

\subsection{Layout Design}

This paper focuses on the design of lowcarbon applied to strategic plan in steel logistics park, learn from the experience of domestic and foreign low-carbon park planning and construction, can implement low-carbon form from the following two perspectives.

First, the application of green layout, reverse cycle system construction and energy-conserving application of building. Drawing lessons from the afforesting standard of Germany logistics park, inner green coverage of low-carbon logistics park should reach $25 \%-30 \%$. The greenbelt, besides absorbing the carbon dioxide, can also absorb the rainwater. The park can be set to water reuse technology, processing storm water, waste water that produce in the park, then used for the use of landscaping, car washing and other purposes.

Second, implement logistics activities of high efficient, energy conserving and low carbon. To "reduce, recycle, reuse" as target, organize logistics activities, save resources and energy consumption, reduce logistics costs and improve economic benefits and ecological benefits.

\subsection{Business Model and Strategies}

4.5.1 Business model: $H$ steel logistics park operators should provide the infra- 
structure and trading platform service, settled companies pay administration expense, facility rental fees and every professional service expenses, regional government can offer tax incentives to local businesses registered to pay taxes. $\mathrm{H}$ steel logistics park establishes management committee in the park, conferring decisions of park public affairs together, supervising the operator's business activities.

\subsubsection{Business strategies:}

a) Reform traditional steel products stock transaction mode, through putting up the electronic trading platform, to achieve steel products electronic trading. On this basis, the integration of electronic trade and logistics service innovative service method.

b) Pay attention to the realization of lowcarbon development model running in the garden. In term of urban development planning and urban network layout, implement industrial clusters, reduce logistics activities among supply chain enterprises. According to idea of circular economy, park's logistics system planning should combine forward logistics with reverse logistics, to set up a low-carbon logistics mode, which take into account the optimization of economic benefits and environmental benefits. Its essence is to achieve a benign cycle of logistics and thrift of resource energy.

\section{Conclusion}

Low carbon type steel logistics park have important strategy meanings, in realizing steel logistics industry developed with environment in harmony, and the unity of economic benefits, social benefits and ecological benefits. This paper uses lowcarbon idea in steel logistics field, adopts MSFLB logistics park planning methodology to construct planning framework of low-carbon type steel logistics park in our country and designs initial planning and business mode in the instance. This paper focuses on theoretical application of MSFLB logistics park planning methodology, in order to provide ideas of lowcarbon type steel logistics park planning and operation for our country.

\section{References}

[1] Shang Pu consults: Four major developing direction of China's iron and steel logistics industry, August 2011, China's economic network, www.ce.cn J. Clerk Maxwell, A Treatise on Electricity and Magnetism, 3rd ed., vol. 2. Oxford: Clarendon, 1892, pp.68-73.

[2] Yan Wei, Mi Weijian. Green reverse logistics [M]. Beijing: People's Transportation Press, March 2011, first published

[3] He Dengcai, Yan Bin, Yuan Youfeng. Study report of Germany's logistics park $[J]$. China's logistics and purchasing, 2010, Vol16,pp58-61.

[4] The Germany Fraunhofer IML of Beijing Representative Office. MSFLB logistics park planning based on three drivers [J ].Logistics technology and application, 2005, (4),pp87

[5] Xing Jijun, Huang Dong, Zhao Gang. Low carbon economy report [R]. Beijing: Electronic Industry Press, July2010

[6] Liu Yinbin, Liu Xiaoxia, Xiong Li. Logistics strategic planning and implementation of [M]. Beijing: Electronic Industry Press, January 2008, first published

[7] Zhu PeiPei, Xu Xu. Study on lowcarbon logistics development model based on cycle economy [J ]. Productivity research, 2011, 2,pp13 